\title{
A Study of the Effects of Total Quality Management on Occupational Safety Regulations
}

\author{
Selman AKSOY \\ Düzce University, \\ Department of Occupational Health and Safety, Düzce \\ Mehmet KAHRAMAN \\ Mehmet Akif Ersoy University, \\ Faculty of Economics and Administrative Sciences, \\ Business Administration Department, Burdur
}

\begin{abstract}
The aim of this study is to determine the role of total quality management (TQM) in controlling occupational health and safety operations which is highly significant to enterprises. Data has been obtained by survey technique which is one of the initial collection techniques. A questionnaire with 34 questions used by Güngör (2008) earlier has been conducted. Data has been attained from the employees' answers to the questions of the survey who work at two different machine-manufacturing enterprises. Enterprises have been chosen intentionally from those that one of them applies TQM and the other doesn't. Data was analyzed by SPSS-20 software. At the end of the research, it has been revealed that the enterprise which implements $T Q M$, has more regulations about occupational safety than the other enterprise which doesn't implement TQM. In conclusion, it has been detected that the TQM applications have a positive effect on occupational safety regulations.
\end{abstract}

Keywords: Total Quality, Machine Production Industry, Occupational Safety

\section{Introduction}

Occupational health and safety (OHS) can plainly be defined as providing safe working conditions for employees. Subjects about employees' safety are getting more important not only at working environments but also in every segment of society (Keleş, 2005).

Every 15 seconds, 160 workers are exposed to occupational accidents and 1 worker dies due to occupational accident and/or occupational disease worldwide. As a result of occupational accidents or occupational diseases daily 6.300 workers, annually 2.3 million workers lose their life. As a result of occupational accidents, absenteeism figures reach over 337 million every year. Health and safety conditions at workplaces profoundly vary depending on social groups, industries and countries (Kılkış \& Demir, 2012). In developing countries where national economy highly depends on dangerous industries such as agriculture, mining and fishery, injuries and deaths have been experienced more frequently. Besides, particular social groups such as immigrants, children and women especially in poor countries are affected the most by occupational accidents and diseases (MMO, 2012).

According to figures of International Labour Organisation (ILO) the total cost of occupational accidents and diseases in industrialised economies holds $\% 1-\% 3$ of Gross Domestic Product (GDP). It is estimated that the total cost of occupational accidents and diseases in developing countries holds around \%4 of GDP (Ceylan, 2011).

It is clearly understood that the situation in Turkey is desperate when the death figures are examined depending on occupational accidents. Occupational accident and death figures during the last decade are indicated at Table 1. This data consists of accident statistics which have officially been reported to Social Security Institution (SSI) of Turkey. Unfortunately most of the accidents occur in Turkey are not officially recorded. The recorded accident figures are less than 70 thousand in a population of 75 million. The number of occupational accidents reaches 800 thousand in Germany with a population of 83 million. It can be inferred that all accidents in Turkey are not recorded in comparison to Germany (Ceylan, 2011). 
Table 1 Number of deaths in Turkey as a result of occupational accidents (2000-2012) [5].

\begin{tabular}{|l|l|l|}
\hline YEAR & NUMBER OF OCCUPATIONAL ACCIDENTS & NUMBER OF DEATHS \\
\hline 2000 & 74847 & 1173 \\
\hline 2001 & 72367 & 1008 \\
\hline 2002 & 72344 & 878 \\
\hline 2003 & 76668 & 811 \\
\hline 2004 & 83830 & 843 \\
\hline 2005 & 73923 & 1096 \\
\hline 2006 & 97027 & 1601 \\
\hline 2007 & 80602 & 1044 \\
\hline 2008 & 72963 & 866 \\
\hline 2009 & 64316 & 1171 \\
\hline 2010 & 63903 & 1444 \\
\hline 2011 & 69227 & 1700 \\
\hline 2012 & 74871 & 774 \\
\hline
\end{tabular}

According to 2012 statistics of Social Security Institution (SSI); 74871 occupational accidents, 2036 incapacities and 774 death incidents had been occurred. When the figures are examined in terms of employee, employer and the state, the extent of financial and emotional loses increase (SGK, 2013). In this sense, Total Quality Management (TQM) applications play a significant role in minimizing the number of accidents and deaths at workplaces. In this study, it has been attempted to find out the effect of TQM applications on occupational health and safety studies which makes this study important.

Occupational accidents and diseases in Turkey considering the loses above is appeared to be a significant issue. Occupational accidents cause deaths of thousands of people, disability as well as emergence of serious economic loses. Occupational accidents are mutual problem of all countries and the studies indicate that the accidents can be minimized by taking necessary measures. Countries which are inadequate to take necessary measures have been affected by the accidents more than the other countries (Ceylan, 2012).

Many countries have made remarkable progress in forestalling occupational accidents in recent years (Keleş, 2005). In addition, improvements in TQM have positively affected the occupational health and safety area. TQM considers person the most significant value of the organisation and also represents a quality system where all the workers are responsible for. The most significant dimension of TQM is providing to create a safety culture at workplaces in order to reduce occupational accidents or even avoid them before they occur (Duran \& Çetindere, 2012). Occupational health and safety management system (OHSAS 18001) which is essential part of TQM has been structured to meet health and safety obligations efficiently at workplaces. Thus, the repetition of accidents will be avoided by creating an effective safety culture. It is possible to maintain production processes with a result of customer satisfaction by providing safety working environment. Employees and managers who are responsible for quality of products and manufacturing processes are also the leaders of TQM operations. (Ofluoğlu \& Sarıkaya, 2005).

Contemporary management approaches assume that human factor is the leading factor to the success of organisations. Therefore physical and psychological states of employees as well as their attitudes towards the organisation are getting more important. In this sense, occupational health and safety culture and its implementations at workplace take one of the most significant roles of the organisation (Zorlu, 2008). 
In Turkey working population has been shifting from agriculture sector to manufacturing industry. Therefore studies about occupational health and safety become more important as the figures of labour force increases. The main reason that occupational health and safety studies are constantly gaining more importance is because the numbers of occupational accidents and diseases have been increasing due to insecure and risky workplaces which cause more deaths and injuries (Aydın, Karaca \& Özgüler, 2013)

In this research TQM's role in the studies of OHS has been examined which improves OHS performances of enterprises and also provides proactive approaches to prevent occupational accidents and diseases before the risks have not emerged at workplaces (Ofluoğlu \& Sarıkaya, 2005). Recently, the number of academic researches and studies about OHS has increased. However researches which examine the effect of TQM on OHS are quite few. In this sense, it is thought that this study would enrich the literature.

\section{RESEARCH METHOD AND RESEARCH QUESTION}

In this research, survey method has been used as a data collection tool. It has been profited by the questionnaire which was developed by Güngör(2008). Questionnaire consists of 34 questions and it has been organised convenient to Likert scale that can be rated on 1-5. In order to find out the efficiency of TQM which is the main subject of the research, two enterprises have been chosen in Istanbul. Both enterprises manufacture machine while one of them implements TQM principles and the other one doesn't. Survey has been conducted among 274 employees; 160 of them are from the enterprise where TQM principles are implemented, 114 of them are from the enterprise where TQM principles are not implemented.

In this study it has been examined and attempted to understand whether there is a different thinking about the effect of TQM applications on OHS studies among employees. According to this, research question has been formed. Research question reveals the relation between two or more variables but defines this relation with a question (CWU, 2014). For that purpose it has been attempted to answer the following question below.

Is there a meaningful difference between the viewpoints of employees from the enterprise where TQM principles are applied and employees from the enterprise where TQM principles are not applied?

\section{RELIABILITY}

Totally 274 questionnaires have been evaluated in the study. Cronbach Alpha value has been taken into account as the general reliability was being examined in the questionnaires. The values calculated over 0,70 are reliable values (Bayram, 2012).

Reliability results that have been obtained by SPSS20 are indicated at table 2 below.

Table 2. Reliability test table of the conducted survey

\begin{tabular}{|l|l|l|}
\hline Cronbach's Alpha & $\begin{array}{l}\text { Cronbach's Alpha Based on } \\
\text { Standardized Items }\end{array}$ & of Items \\
\hline, 979 & 0,979 & 34 \\
\hline
\end{tabular}

As a result of reliability test, Alpha value had the value of 0,979 . This value indicates that the survey has a high reliability. In Güngör's study Alpha value was resulted as 0,978 . Values that have been reached by these two studies are approximately the same.

\section{FINDINGS}

In this study factor analysis method has been implemented. Besides, with the help of Kaiser-Mayer-Olkin test (KMO) and Bartlett test of sphericity, it was decided whether it's possible to use factor analysis. Factor analysis is a statistical technique which enables to obtain few unrelated variables by getting the variables interrelated together when the number of data is very high (Çelik, 2012). The most common practice of factor analysis is principal component analysis. This analysis eliminates dependency between many variables and also provides us to acquire fewer new variables (Polat, 2012). In this 
sense, principal component analysis has been used in order to reduce numerous variables to fewer variables. As a result of analysis, three components (factor) - in other words - variable groups have been formed.

When the perceptions of employees are examined in terms of occupational health and safety management system, according to survey results; average values are in the range of 4,237 to 2,9562 at the enterprise where TQM is applied and average values are in the range of 2,8333 to 1,6579 where TQM is not applied.

Table 3. KMO and Barlet test

\begin{tabular}{|l|l|}
\hline Kaiser-Meyer-Olkin Measure of Sampling Adequacy. &, 973 \\
\hline Approx. Chi-Square & 8830,157 \\
\hline Bartlett's Test of Sphericity Df & 56 \\
\hline Sig. &, 000 \\
\hline
\end{tabular}

Data indicated at table 3 according to KMO and Barlett's test, sample appropriateness value (0.973) points out a normal distribution of data and also appropriateness for factor analysis."Chi-Square" value (8830.157) with a meaningful result $(p=.000<0.05)$ is an indication for the validity of the result of factor analysis.

Table 4. Factor analysis for determining perceptions of the employees' application-level of occupational health and safety management system

\begin{tabular}{|l|l|l|l|l|}
\hline & $\begin{array}{l}\text { Factor } \\
\text { Load }\end{array}$ & Average & Eigenvalue & $\begin{array}{l}\text { Explained } \\
\text { Variance }\end{array}$ \\
\hline $\begin{array}{l}\text { "Responsibilities of the employees and the employer } \\
\text { at workplace" factors }\end{array}$ & & $\mathbf{2 , 9 4 0 3}$ & $\mathbf{2 0 , 4 2 0}$ & $\mathbf{2 5 , 5 8 0}$ \\
\hline $\begin{array}{l}\text { It is benefitted from the studies of employee-occupational } \\
\text { adaptation in order to prevent occupational accidents }\end{array}$ & $\mathbf{, 8 0 7}$ & & & \\
\hline $\begin{array}{l}\text { Internal auditing is done according to determined } \\
\text { plans }\end{array}$ & $\mathbf{, 7 0 4}$ & & & \\
\hline $\begin{array}{l}\text { Collaboration and coordination regarding } \\
\text { occupational health and safety is provided } \\
\text { throughout the enterprise }\end{array}$ & $\mathbf{, 7 0 3}$ & & & \\
\hline $\begin{array}{l}\text { Methods like IQ test, medical examination, } \\
\text { psychotechnic test etc. are used during recruitment } \\
\text { stage in order to select convenient employee who } \\
\text { has the qualifications required for the job }\end{array}$ & $\mathbf{, 6 7 7}$ & & & \\
\hline $\begin{array}{l}\text { Organizational structure of our organisation has } \\
\text { been identified. (Organization Chart) }\end{array}$ & $\mathbf{, 6 6 5}$ & & & \\
\hline $\begin{array}{l}\text { It is complied with relevant legislation to prevent } \\
\text { occupational accidents. }\end{array}$ & $\mathbf{, 6 5 6}$ & & & \\
\hline $\begin{array}{l}\text { Occupational health and safety researches and } \\
\text { accident analysises are conducted regularly to } \\
\text { prevent occupational accidents }\end{array}$ & $\mathbf{, 6 3 0}$ & & & \\
\hline $\begin{array}{l}\text { Periodic control and maintenance of machinery and } \\
\text { equipments are done. }\end{array}$ & $\mathbf{, 6 1 9}$ & & & \\
\hline
\end{tabular}


Employees are trained by a specific training programme to prevent occupational accidents and diseases

Occupational health and safety committee is effective in the prevention of occupational accidents and diseases in our enterprise.

Noise measurements are made in noisy areas and measures are taken against noise.

Risk assessment is conducted in order to prevent occupational accidents.

In order prevent occupational accidents; there is a barrier or a distance between the employees who are busy with hazardous occupation and the others.

Plans are made to apply risk control methods. "Training and internal control" factors

All staff is trained about occupational health and safety.

Employees get periodic health checks in accordance with the legislation from the beginning of the recruitment.

Our enterprise has a permanent workplace doctor for the period specified in law.

Employees who are necessarily need the training about occupational health and safety are trained

Personal protective equipments and warning signs related to occupational health and safety are used.

Employees are trained about occupational health and safety

Accident and injury report is subsequently prepared when an accident occurs.

Accident statistics are recorded regularly

Records and data related to occupational accidents are kept adequately.

There is a certified first aid team which is actively working.

Enterprise is controlled by the state and private institutions in terms of occupational health and safety

Orientation training is being performed for the new employees to prevent occupational accidents

\section{"Occupational diseases and risk assessment"} factors

There is a ventilation system for prevention of occupational diseases.

\begin{tabular}{|c|c|c|c|}
\hline ,608 & & & \\
\hline ,602 & & & \\
\hline \multicolumn{4}{|l|}{,588 } \\
\hline \multicolumn{4}{|l|}{,574 } \\
\hline \multicolumn{4}{|l|}{,556 } \\
\hline \multicolumn{4}{|l|}{,537 } \\
\hline & 3,2737 & 1,534 & 24,643 \\
\hline \multicolumn{4}{|l|}{,722 } \\
\hline \multicolumn{4}{|l|}{,705 } \\
\hline \multicolumn{4}{|l|}{,701 } \\
\hline \multicolumn{4}{|l|}{,669 } \\
\hline \multicolumn{4}{|l|}{,655 } \\
\hline \multicolumn{4}{|l|}{,648 } \\
\hline \multicolumn{4}{|l|}{,637 } \\
\hline \multicolumn{4}{|l|}{,624 } \\
\hline \multicolumn{4}{|l|}{,605 } \\
\hline \multicolumn{4}{|l|}{,585 } \\
\hline \multicolumn{4}{|l|}{,505 } \\
\hline \multicolumn{4}{|l|}{,468 } \\
\hline & 2,8864 & 1,067 & 17,487 \\
\hline ,852 & & & \\
\hline
\end{tabular}




\begin{tabular}{|l|l|l|l|l|}
\hline $\begin{array}{l}\text { We are trying to avoid circulation of dust with the } \\
\text { help of water in order to prevent occupational } \\
\text { diseases }\end{array}$ & $\mathbf{7 3 3}$ & & & \\
\hline $\begin{array}{l}\text { Hazardous materials is physically separated from } \\
\text { the working environment in order to prevent } \\
\text { occupational diseases }\end{array}$ & $\mathbf{, 6 0 9}$ & & & \\
\hline $\begin{array}{l}\text { Attention and support of managers regarding } \\
\text { occupational health and safety is sufficient }\end{array}$ & $\mathbf{5 8 8}$ & & & \\
\hline $\begin{array}{l}\text { Risk assessment is used for preventing the repetition } \\
\text { of damage or harm that has already emerged. }\end{array}$ & $\mathbf{5 8 5}$ & & & \\
\hline $\begin{array}{l}\text { Risk assessment is used for preventing the } \\
\text { emergence of harm and damage as a proactive } \\
\text { method. }\end{array}$ & $\mathbf{, 5 2 5}$ & & & \\
\hline $\begin{array}{l}\text { Instead of very hazardous substances less harmful } \\
\text { substances are used to prevent occupational } \\
\text { diseases. }\end{array}$ & $\mathbf{5 0 7}$ & & & \\
\hline $\begin{array}{l}\text { Managers are trained about occupational health and } \\
\text { safety }\end{array}$ & $\mathbf{, 4 4 8}$ & & & \\
\hline
\end{tabular}

Perspectives of employees were gathered under 3 factors according to eigen value criterion. Initial factor was described as "responsibilities of the employees and the employer at workplace". Responsibility factor of the employees and the employer has an eigen value of 20,420 at workplace. This value explains $\% 25,580$ of total variance. The average value of participants' answers to this factor is 2, 9403. According to this value participants think that employees and the employer have some responsibilities to reduce occupational accidents and diseases.

The second factor attained was described as "training and internal control". Eigen value of this factor equals to 1,534. This value explains $\% 24,643$ of total variance. The average value of participants' answers to this factor is 3,2737 . Participants remark that training and internal control are effective on occupational safety regulations.

As a result of factor analysis the third factor was described as "occupational diseases and risk assessment". The eigen value of this factor is 1,067 . This value explains $\% 17,487$ of TQM's role in occupational safety studies in other words $\%$ 17,487 of total variance. The average value of participants' answers to the questions of "occupational diseases and risk" factor is 2, 8864. Participants' thoughts are moderate about the decrease of occupational accidents and diseases in case of eliminating risks.

The obtained 3 factors explain $\% 68$ of total variance.

\section{ANALYSIS OF RESEARCH QUESTION WITH T TEST}

Research question was already determined as "Is there a meaningful difference between the viewpoints of employees from the enterprise where TQM principles are implemented and employees from the enterprise where TQM principles are not implemented?". At this stage in order to analyze the question "T test for independent samples" has been conducted. T test results are indicated at table 5 and table 6.

Table 5. Group Statistics of factors

\begin{tabular}{|l|l|l|l|l|l|}
\hline Factors & $\begin{array}{l}\text { Total quality } \\
\text { management }\end{array}$ & $\mathbf{N}$ & Average & Standard deviation & $\begin{array}{l}\text { Average of Standard } \\
\text { error }\end{array}$ \\
\hline
\end{tabular}




\begin{tabular}{|l|l|l|l|l|l|}
\hline $\begin{array}{l}\text { Responsibilities of } \\
\text { the employees and } \\
\text { the employer at } \\
\text { workplace }\end{array}$ & Applied & 160 & 3.6013 & 0.73682 & 0.05825 \\
\hline $\begin{array}{l}\text { Training and internal } \\
\text { control }\end{array}$ & Applied & 114 & 2.0125 & 0.69993 & 0.06555 \\
\hline $\begin{array}{l}\text { Occupational } \\
\text { diseases and risk } \\
\text { assessment }\end{array}$ & Not applied & 114 & 2.4020 & 0.62459 & 0.05506 \\
\hline & Not applied & 114 & 2.1765 & 0.62551 & 0.05850 \\
\hline
\end{tabular}

Table 6. Independent samples t-test results of the factor

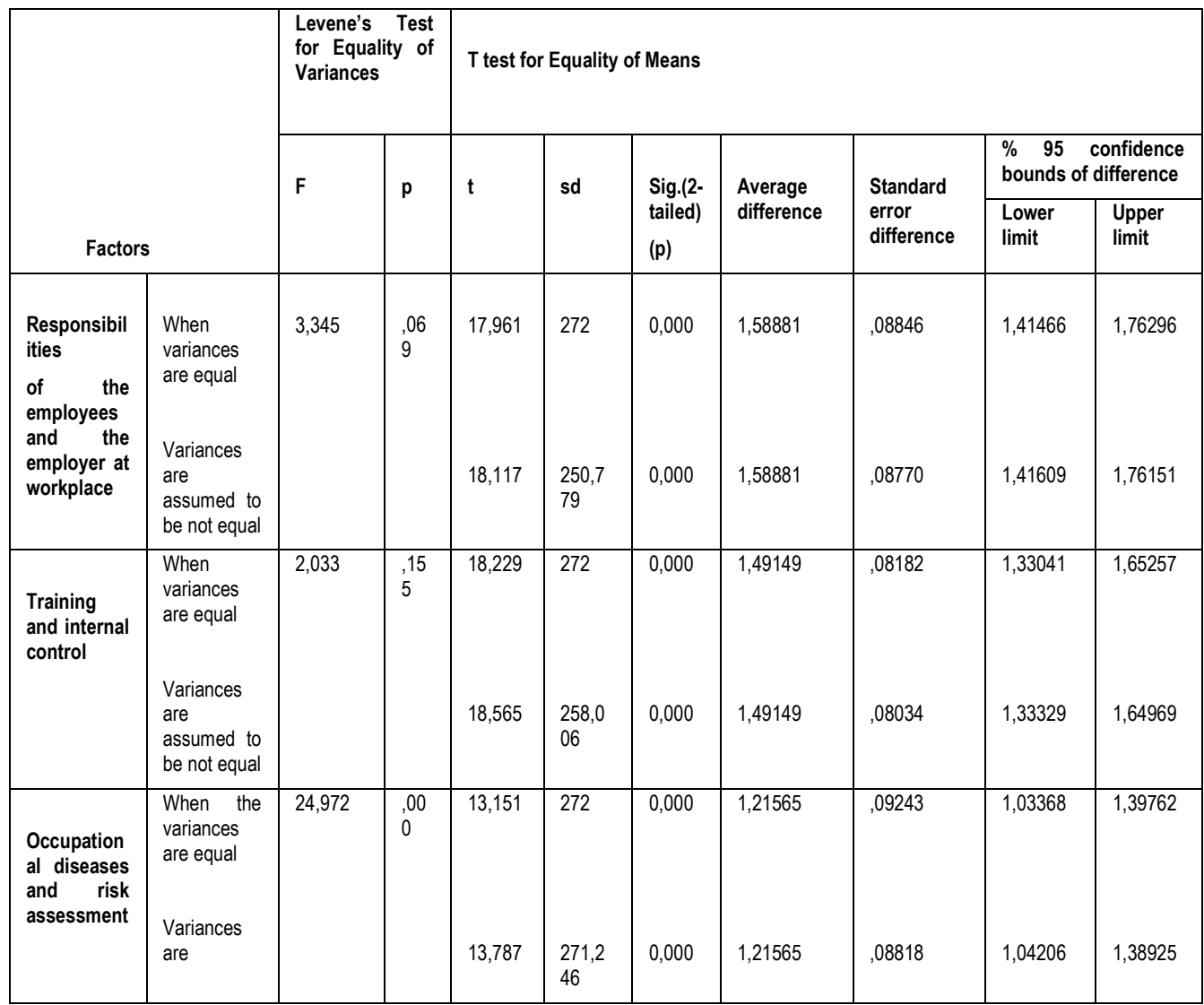




\begin{tabular}{|l|l|l|l|l|l|l|l|l|l|}
\hline $\begin{array}{l}\text { assumed to } \\
\text { be not equal }\end{array}$ & & & & & & & & & \\
\hline
\end{tabular}

It is seen that the responsibility factor value equals to 0.00 at Sig.(2-tailed) column. It can be stated that there is a meaningful difference between the enterprise where TQM is applied and the enterprise where TQM isn't applied, because the calculated value is less than 0.05 . When the group statistics of factors are examined at table 5 , it is seen that the average value (3.6013) of enterprise where TQM is applied is higher than the average value (2.0125) of the enterprise where TQM is not applied. According to these values it can be inferred that the participants think that the responsibilities of the employees and the employer from the enterprise where TQM is applied, is more effective on occupational safety operations than the enterprise where TQM is not applied.

When the results of $t$ test are examined for training and internal factor Sig. (2-tailored) value is seen as 0.00 . Because the value is less than 0.05 , for this factor it can be stated too that there is a meaningful difference between the enterprise where TQM applied and the enterprise where TQM isn't applied. When the group statistics of factors are examined at table 5, it is seen that the average value (3.8943) of enterprise where TQM is applied is higher than the average value (2.4020) of the enterprise where TQM is not applied. Considering these values training and internal control factor is thought to reduce occupational accidents and diseases more effectively at the enterprise where TQM is applied.

The value at the t-test table Sig. (2-tailed) equals to 0.00 for occupational diseases and risk assessment factor. It indicates that occupational diseases and risk assessment factor differs meaningfully between the enterprise where TQM is applied and the enterprise where TQM isn't applied. Average value at table 5 for the enterprise where TQM is applied is 3.3922 for the enterprise where TQM is not applied is 2.1765. Considering the answers to the questions of the employees from the enterprise where TQM is applied, it can be inferred that this factor is thought to be effective on occupational safety operations.

\section{CONCLUSION}

In this study, the effect of total quality management to the occupational safety has been researched with an application at the machine-manufacturing industry. 74871 occupational accidents occurred in 2012 . When the distribution of occupational accidents is examined according to operation groups, some of the accident figures at machine-manufacturing industry are as following; metal goods 7045 , main metal industry 4938 , machine and equipment manufacturing 2235 , motor vehicles and trailer manufacturing 1796, machine and equipment set up and maintenance 1045. The sum of the figures equals to 17.059. This figure indicates that the enterprises at machine-manufacturing industry have the highest accident rate (MMO, 2015). For this reason occupational health and safety emerges as an important issue at the enterprises of machine-manufacturing industry. Occupational safety regulations cover operations that prevent employees, production process as well as enterprise from damage and harm. TQM is one of the elements which has these operations. Measuring the effect level of TQM through perspectives of employees is the main subject of this research.

Through factor analysis that has been applied on the data obtained from employees, viewpoints of the employees who work at 2 different enterprises have been gathered under 3 factors. These factors are as the following; "responsibilities of the employees and the employer at workplace", "training and internal control", "occupational diseases and risk assessment".

In order to find out whether there is a difference between the perception of employees from the enterprise where TQM is applied and perception of employees from the enterprise where TQM is not applied in terms of occupational safety regulations, T test was conducted and for all 3 factors differences between perceptions of employees have been detected.

Despite the fact that there are many researches and studies related to OHS, there are only few studies about the effect of TQM on OHS regulations. This study has generally reached similar findings to the literature. Gungor (2008) deduced that applying TQM principles at enterprises efficiently has a positive effect on reducing occupational accidents and diseases.

Keleş (2005) examined the role of OHS within TQM and remarked that combining TQM with OHS operations would increase the productivity and employees would be more participant. Furthermore it was emphasized that TQM operations could be 
more effective by conducting risk management and hazard analysis in terms of bringing occupational accidents and diseases under control.

Attempts to decrease the amount of occupational accidents and diseases have a high importance for each enterprise. It is very significant to raise awareness among employees about the risks and hazards at workplace right after conducting risk analysis. In Turkey a new OHS law (Resmi Gazete, 2014) passed with number of 6331 in 20.06 .2012 which gives particular responsibilities to both the employees and the employer. By this operation in law, risk analysis became a must at enterprises consequently employees had an advantage of working in a safer environment more productively.

There is a significant correlation between minimizing occupational accidents and diseases and carrying out TQM applications properly and efficiently. Conducting risk analysis in order to determine risks and hazards, eliminating the risks exist or minimizing them to acceptable levels, increasing the number of trainings for staff, improving the performance of OHS operations, taking a proactive approach against occupational accidents and diseases are related to TQM and its principles. Besides it's a necessity to apply the current law, rules and regulations in order to provide a safer working environment.

Managerial staff should have sufficient knowledge about OHS and pay more attention to occupational safety applications. Thus employees are more stimulated to be conscious towards risks and hazards at workplace. In this sense employees should undergo intensive training to avoid insecure operations and actions which cause serious damages and harms at workplace (Demirbilek \& Çakır, 2008).

As it is well-known, reducing occupational accidents and diseases or completely avoiding them to happen is of a great benefit to employees and employers as well as state. Furthermore it would boost productivity, effectiveness and efficiency and also support sustainable development.

In conclusion, it is highly important to adopt TQM principles by all the members of an enterprise and embrace it as an aspect of organizational culture, thus it would be much easier to set up occupational safety organisations and bring occupational accidents and diseases under control.

\section{References}

[1] Keleş R., (2005 November 09-12) "The role of occupational health and safety in total quality management", 4th Research/Expert Conference with International Participations, "QUALITY 2005", Fojnica, B\&H.

[2] Kılkış, I.\& Demir, S.(2012) "Işverenin iş sağliği ve güvenliği eğitimi verme yükümlülüğü üzerine bir inceleme", Çalışma Illişkileri Dergisi, Cilt 3, Sayı 1, 23-47.

[3] İşçi Sağlığı ve Iş Güvenliği Oda Raporu, MMO Yayınları, (2012).

[4] Ceylan, H.(2011) “Türkiye'deki iş kazalarinin genel görünümü ve gelişmiş ülkelerle kiyaslanmasi”, İnternational Journal of Engineering Research and Development,Vol.3, No:2, 18-24.

[5] http://www.sgk.gov.tr/wps/portal/tr/kurumsal/istatistikler/sgk_istatistik_yilliklari (2013).

[6] Ceylan, H.(2012) "Türkiye'deki iş sağliği ve güvenliği eğitimi sorunlar ve çözüm önerileri” Electronic Journal of Vocational Colleges, No:1, 94-104.

[7] Duran, C. \& Çetindere, A.(2012) "Kalite yönetimi uygulamalarinda bilgi yönetimi etkilerinin araştirilmasi: Bursa örneği" Üretim araştırmaları sempozyumu,, Gediz Üniversitesi.

[8] Ofluoğlu G. \& Sarıkaya G.(2005) "OHSAS 18001 İş sağlığı ve güvenliği yönetim sistemi”, Kamu-ls.

[9] Zorlu, A.V.(2008) "İnsan kaynaklari açisindan işçi sağliği ve iş güvenliği tedbirleri ve konuyla ilgili bir araştirma”, İstanbul Üniversitesi Sosyal Bilimler Enstitüsü İşletme Anabilim Dalı, İnsan Kaynakları Bilim Dalı, Yüksek Lisans Tezi, İstanbul.

[10] Aydın, U., Karaca , N. G., Özgüler, V. C., Karaca, E. (2013) "İ̧̧ sağliği ve güvenliği eğitiminin iş kazalari ve meslek hastaliklarinin önlenmesindeki rolü" Çimento Endüstrisi İşverenleri Sendikası, Cilt:27, Sayı:4, 24-45.

[11] http://www.cwu.edu/ gellenbe/480/assignments/researchProposalElements.pdf (25.10.2014) 
[12] Bayram, N. (2012), "Sosyal Bilimlerde SPSS ile Veri Analizi”, Ezgi Kitabevi, 194, Bursa.

[13] Çelik, Ş.(2012), "Türkiye'de illerin bitkisel üretiminin faktör analizi ile incelenmesi” YYÜ Tar. Bil. Dergisi, 22(2): 69-76.

[14] Polat, Y.(2012), "Faktör analizi yöntemlerinin karşilaştirmali olarak incelenmesi ve hayvancilik denemesine uygulanişi”, Çukurova Üniversitesi Fen Bilimleri Enstitüsü, Zootekni Anabilim Dalı, DoktoraTezi, Adana.

[15] İşçi Sağlığı ve İş Güvenliği Oda Raporu, MMO Yayınları, (2014).

[16] Güngör, E.(2008), "Iş sağliği ve güvenliği kavraminin toplam kalite yönetimi açisindan irdelenmesi ve talaşli üretim sanayisinde iş sağliği ve güvenliği üzerine bir araştirma", Marmara Üniversitesi Sosyal Bilimler Enstitüsü İşletme Anabilim Dalı, Uluslararası Kalite Yönetimi Bilim Dalı, Yüksek LisansTezi, İstanbul.

[17] http://www.resmigazete.gov.tr/eskiler/2012/06/20120630-1.htm (25.10.2014)

[18] Demirbilek, T. \& Çakır Ö. (2008), "kişisel koruyucu donanim kullanimini etkileyen bireysel ve örgütsel değişkenler" Dokuz Eylül Üniversitesi İktisadi ve İdari Bilimler Fakültesi Dergisi, Cilt:23 Sayı:2,173-191. 